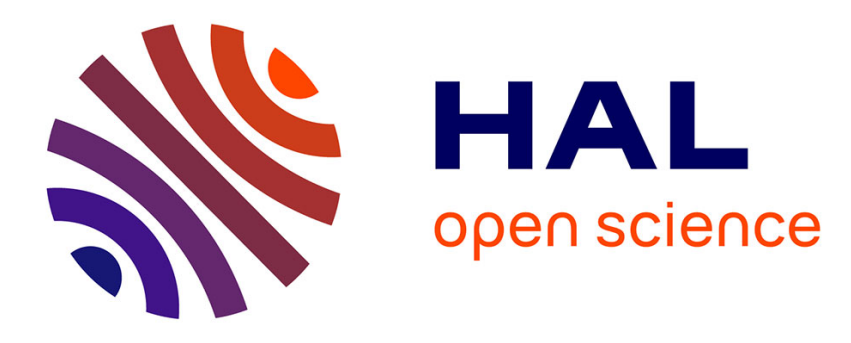

\title{
Semiotics contributions to accessible interface design
}

María Inés Laitano

\section{To cite this version:}

María Inés Laitano. Semiotics contributions to accessible interface design. 12th Web for All Conference, May 2015, Florence, Italy. 10.1145/2745555.2746673 . hal-01196321

\section{HAL Id: hal-01196321 \\ https://hal.science/hal-01196321}

Submitted on 9 Sep 2015

HAL is a multi-disciplinary open access archive for the deposit and dissemination of scientific research documents, whether they are published or not. The documents may come from teaching and research institutions in France or abroad, or from public or private research centers.
L'archive ouverte pluridisciplinaire HAL, est destinée au dépôt et à la diffusion de documents scientifiques de niveau recherche, publiés ou non, émanant des établissements d'enseignement et de recherche français ou étrangers, des laboratoires publics ou privés. 


\title{
Semiotics contributions to accessible interface design
}

\author{
María Inés Laitano \\ Paragraphe Lab. Paris 8 University \\ 2 rue de la Liberté \\ 93526 Saint-Denis (France) \\ ines.laitano@gmail.com
}

\begin{abstract}
The aim of this research is to show that a semiotic approach, similar to those who have already been applied in the HCI field, may contribute to design accessible interfaces. Comparing design solutions from a WCAG approach and from a semiotic approach, we show how the latter can contribute to a real communicational accessibility.
\end{abstract}

\section{Categories and Subject Descriptors}

- Human-centered computing Accessibility theory, concepts and paradigms

\section{General Terms}

Design, Human Factors, Theory.

\section{Keywords}

Semiotics of HCI, interface design, WCAG.

\section{THEORETICAL FRAMEWORK}

All methodological tools imply a theory and the Web Content Accessibility Guidelines (WCAG) are not an exception to the rule. The Essential Components of Web Accessibility (Figure 1) synthesize the theoretical assumptions on which the WCAG and other Web Accessibility Initiative (WAI) guidelines were developed. The model proposes that developers create content (information plus markup language) using authoring and evaluation tools. Users access the content using different user agents. Thus, the WCAG indicate how to proceed in order that everyone can access that content. In short, content is the central notion among Essential Components of Web Accessibility.

Semiotic theory has already been applied to interface design in the Human Computer Interaction (HCI) field [1, 5, 11], proposing an alternative approach to communication between designers and users. From a semiotic point of view, designers have a communication strategy towards a target audience or user group [2, 6, 8]. For example, in an e-commerce website, designers opt for an influential strategy in order to push users-

Permission to make digital or hard copies of part or all of this work for personal or classroom use is granted without fee provided that copies are not made or distributed for profit or commercial advantage and that copies bear this notice and the full citation on the first page. Copyrights for thirdparty components of this work must be honored. For all other uses, contact the Owner/Author.

Copyright is held by the owner/author(s).

W4A '15, May 18-20, 2015, Florence, Italy

ACM 978-1-4503-3342-9/15/05.

http://dx.doi.org/10.1145/2745555.2746673 customers to buy. Interface components are designed and organized according to this strategy and the resulting layout is called editorial enunciation [10]. Note that, compared with the WAI model, the notion of designers is broader in this approach: designers include both interface developers and interface "owners".

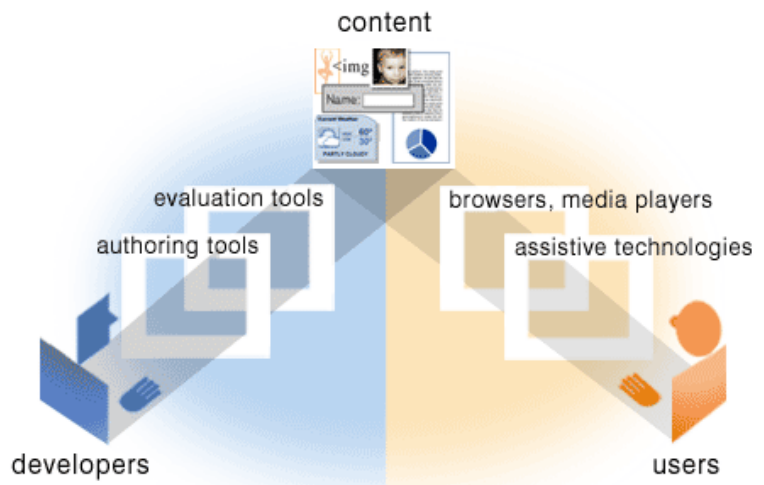

Figure 1. Essential Components of Web Accessibility [3], (c)W3C

Communication between designers and users is not a face-to-face communication. As designers and users do not share the same space-time situation, communication between them is deferred. Therefore, designers can not accurately predict the interface interpretation that will make the user, they can only hypothesize it. Semiotics applied to HCI argues that interface carries an implicit user, i.e., a hypothesis of user behavior, a presumption about user experience, competence and expectations [9]. Communication is only possible if the empirical user (a real user in a use situation) recognize herself in this implicit user.

\section{METHODOLOGY}

We worked on a corpus of inaccessible websites, proposing accessible solutions from both content approach as well as semiotic approach. The results obtained were compared in order to analyze the benefits of applying a semiotic approach.

\section{CURRENT RESULTS}

Contributions that a semiotic approach can make to content approach are illustrated below from a particular case. A research institute want to design its accessible institutional website. The communication strategy seeks to emphasize the regional identity of the whole institute as well as the individual identity of each research team. For this, the institute chooses works of a regional artist integrating autochthonous elements. Each work is chosen to refer to a research team based on its symbolic relationship with the identity of this team. The figure presents a first visual 
mockup of the website home. The main area is occupied by six images (artworks). Each image corresponds to a research institute. Furthermore, each image serves as anchor of the hyperlink that opens the team webpage.

An accessible design of this home from a WCAG 2.0 approach [12] will probably consider that artworks are decorative images within hyperlink texts. Consequently, empty ALT attributes will be used to avoid redundancy and repetition. It is clear that, with this solution, the communication strategy of the designer is completely overridden for people who cannot see images. Instead, an accessible design from a semiotic approach prioritizes and preserves the communication strategy. One possible solution is to associate a short sound to each research team. The sounds are electroacoustic compositions that combine musical sounds with sound effects. The musical sounds evoke, by semantic listening [7], the regional identity of the institute. The sound effects are auditory icons [4] whose referents are associated with the research team they represent. Remember that semantic listen is the mode of listening in contexts involving coded audio signals where the listener focuses on decoding that signal to arrive at the message. Auditory icons instead call for causal listening, that is, listening for the clues in sounds that point to the sound's cause.

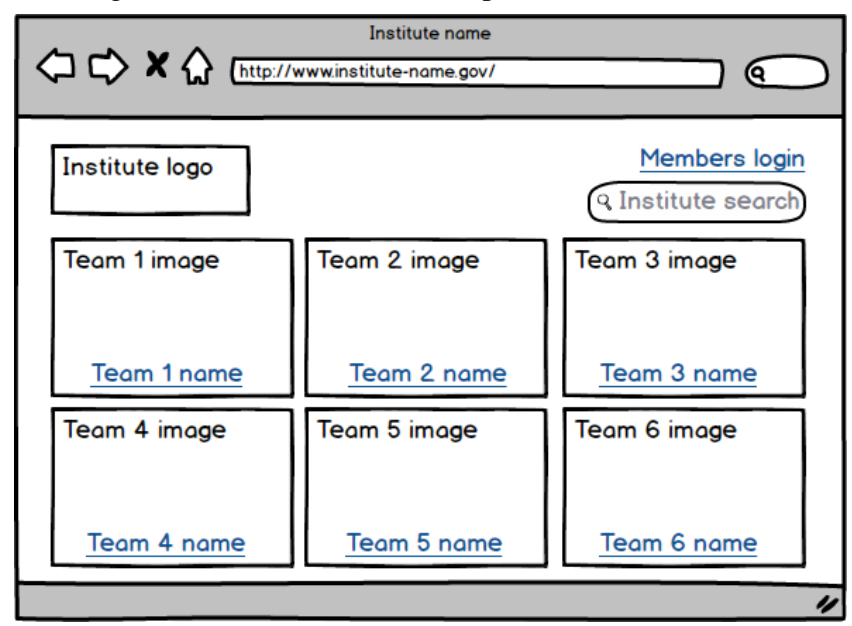

Figure 2. Wireframe of the research institute website home

Another point to address for accessible design is the order of the webpage components when navigating sequentially. The WCAG 2.0 suggest providing an order that follows sequences and relationships within the content, as well as mechanisms to bypass blocks of content. In the case of the research institute home, this means navigate from left to right and top to bottom: start with the header components (logo, login hyperlink and search field) and continue through the main content components (team 1 , team 2 , etc.). Furthermore, shortcuts to jump between the header and the main content can be provided (hyperlinks or landmarks). However, from a semiotic approach, visual editorial enunciation prioritizes main content over the header: the artworks size aims to draw the users' attention. The communication strategy is revealed in the main content. Whereupon, since this approach, it would be more appropriate that the default order begins with the main content components and continue with the header components. Jump shortcuts can be maintained.

The name given to each component of the interface is another important accessible design issue. For example, the WCAG 2.0 suggest that the text of each hyperlink should describe the purpose of the hyperlink, i.e., the nature of the result obtained by activating the hyperlink. From this perspective, a name like "Log in" is sufficient for the hyperlink found on the home header. "Log in" indicates that activating this hyperlink we will find a login webpage. However, this name can be improved by adopting a semiotic approach. The research institute communication strategy targets two audiences: general public and institute members. Only institute members can $\log$ on the website to access information that is not public. Consequently, name the link as "Members login" instead of "Log in" is to set out the implicit users of the interface. Probably the institute members will recognize herself in this hyperlink while non-members shall avoid wasting time activating it.

\section{INTERMEDIATE CONCLUSIONS}

The current results show that complementing the content approach with a semiotic approach means moving from a content accessibility to a communicational accessibility. Communicating accessibly is not only providing content access, it is primarily designing with an accessible communication strategy on mind.

Attending W4A would provide me with the opportunity to discuss this results with international experts and to corroborate the potential impact of my research.

\section{REFERENCES}

[1] Andersen, P.B. 1992. Computer semiotics. Scandinavian Journal of Information sy-stems. 4, (1992), 3-30.

[2] Bootz, P. 2007. Éléments d'analyse de l'interface sémiotique des sites Web. Collaborer, Echanger, Inventer : Expériences de réseaux (Paris, 2007), 107-121.

[3] Essential Components of Web Accessibility: 2005. http://www.w3.org/WAI/intro/components.php. Accessed: 2014-10-20.

[4] Gaver, W.W. 1989. The SonicFinder: An interface that uses auditory icons. Human-Computer Interaction. 4, (1989), 6794.

[5] Nadin, M. 1988. Interface Design: A Semiotic Paradigm. Semiotica. 69, 3-4 (1988), 269-302.

[6] Pignier, N. and Drouillat, B. 2004. Penser le webdesign: modèles sémiotiques pour les projets multimédias. Editions L'Harmattan.

[7] Schaeffer, P. 1967. Traité Des Objets Musicaux. Seuil.

[8] Scolari, C. 2009. The sense of the interface: Applying semiotics to HCI research. Semiotica. 2009, 177 (2009), 127.

[9] Scolari, C.A. 2001. Towards a semio-cognitive theory of Human-Computer Interaction. CHI '01 Extended Abstracts on Human Factors in Computing Systems (New York, 2001), 85-86.

[10] Souchier, E. 1998. L'image du texte pour une théorie de l'énonciation éditoriale. Les cahiers de médiologie. 6, 2 (1998), 137-145.

[11] De Souza, C.S. 2005. The semiotic engineering of humancomputer interaction. MIT Press.

[12] W3C 2008. Web Content Accessibility Guidelines (WCAG) 2.0. 